\title{
Seed priming enhanced seed germination traits of wheat under water, salt and heat stress
}

\author{
Saman Rafique Mirza, Noshin Ilyas*and Nazima Batool \\ Department of Botany, PMAS Arid Agriculture University Shamsa abad Rawalpindi 46300, Pakistan. \\ *Corresponding author's email: noshinilyas@yahoo.com Cell \# +92-333-5310587 \\ Citation \\ Saman Rafique Mirza, Noshin ilyas and Nazima batool. Seed priming Enhanced Seed germination traits of Wheat \\ under water, salt and heat stress. Pure and Applied Biology. Vol. 4, Issue 4, 2015, pp 650-658. \\ http://dx.doi.org/10.19045/bspab.2015.44025
}

Received: 15/06/2015

Revised: 17/11/2015

Accepted: $26 / 11 / 2015$

\section{Abstract}

Abiotic or physicochemical stresses affect plant's internal mechanisms as well as external morphology. Seed priming can be an effective tool to minimize effects of the abiotic stress on plant growth and wheat seed priming used as stress tolerance mechanism. The study was conducted to evaluate effects of seed priming on germination of two wheat varieties under drought, high salt levels and high temperature stress. Hydro priming (distilled water), Osmopriming (5milli molar $\mathrm{KNO}_{3}, 10 \mathrm{mM} \mathrm{KNO}_{3}$ ) and halo priming $(5 \mathrm{mM} \mathrm{NaCl}, 10 \mathrm{mM} \mathrm{NaCl})$ were used. Under drought and heat stress, hydro priming resulted in the highest germination index to increase up to 70 and 65 percent as compared to stressed seeds while under salt stress, 5 $\mathrm{mM} \mathrm{KNO}_{3}$ priming showed highest germination index up to 75 percent. Under salt stress, $5 \mathrm{mM}$ $\mathrm{KNO}_{3}$ priming resulted in highest seedling vigor index with $86 \%$ increase as compared to stressed seeds. Under water and heat stress, hydro primed seeds showed highest percentage i.e. $50 \%$ and $45 \%$ increase in germination stress tolerance index as compared to stressed seeds. Under salinity stress, $5 \mathrm{mM} \mathrm{KNO}_{3}$ primed showed $51 \%$ increase in germination tolerance index as compared to stressed seeds. Seed priming was proved as an effective technique to increase abiotic stress tolerance.

Key words: Wheat seed priming; Abiotic stress; Germination.

\section{Introduction}

Abiotic stress causes a decline in crop growth and productivity. Drought stress causes loss of water use efficacy, induction of heat stress and reduces stem extension. Biological macromolecules are damaged due to the production of free ions [1]. It was found that salinity stress resulted in a decrease of water content, accumulation of hydrogen peroxide and electrolyte release in wheat seedlings $[2,3]$. Enzyme deactivation and change in permeability of membrane are the effects of heat stress [4]. For high yield in annual crops, even and fast field emergence is the primary requirement [5]. For this purpose, seed priming is a suitable technique. Seed priming is a pre-sowing seed treatment. It is partial hydration of seeds performed in controlled conditions while the emergence of radical is avoided by drying before sowing [6]. Hydro priming is immersing of seeds using distilled water. Halo priming is soaking of seeds using 
different salt solutions. Osmopriming is immersing of seeds in different solutions of osmotic concentrations [7]. Seed priming is proved to be a cost effective strategy which is very helpful to increase growth attributes of cereal crops. Soaking of seeds before sowing can enhance the rate of growth and seedling establishment [8, 9]. Keeping above literature in view, the present work was planned to answer the question whether seed priming is effective treatment and which seed priming technique is most effective in relation to respective stress conditions.

\section{Materials and methods}

The research was carried out in the Plant physiology lab, Department of Botany at the Arid Agriculture University to study the role of wheat seed priming in relation to abiotic stress tolerance. Two varieties of wheat i.e. NARC- 2009 and NARC- 2011 were sown. Seed surface sterilization was done [10]. Hydro priming was carried out by soaking seeds in distilled water for 24 hours under lab conditions. Redrying of seeds was done under air after soaking [11]. Osmo priming was carried out by soaking seed in an osmotic solution, i.e. Potassium Nitrate $\left(\mathrm{KNO}_{3}\right)$ for 24 hours under lab conditions. Two concentrations of $\mathrm{KNO}_{3}$ i.e. $5 \mathrm{mM}$ and $10 \mathrm{mM}$ were used. Seeds were washed with distilled water and re-dried their original weight [12]. Halo priming was carried out by soaking seeds in sodium chloride $(\mathrm{NaCl})$ solution for 24 hours under lab conditions. Two concentrations of $\mathrm{NaCl}$ i.e. $5 \mathrm{mM}$ and $10 \mathrm{mM}$ were used. Seeds were washed with distilled water and re-dried to their original weight [13]. Seeds were sown on a moist layer of filter paper in petri plates to monitor germination daily until all seeds were germinated. $5 \mathrm{~mm}$ radical length was taken as criteria to consider seed germinated [14]. Control seeds were irrigated with distilled water. Germination analysis was done on the basis of following parameters.

\section{Germination percentage}

Germination percentage of each treatment was calculated using following formula

Germination $\%$ age $=$

Total seeds germinated x 100

Total no of seeds planted

Germination index (G.I.)

Germination index was calculated using following formula [15].

Germination Index $=\mathrm{n} / \mathrm{d}$

Where $\mathrm{n}=$ no of seedlings emerged on day' $^{\prime} d$ '. $d=$ days after planting.

\section{Promptness index (P.I.)}

Promptness index (P.I) was determined using following equation

Promptness index $(\mathrm{P} . \mathrm{I})=\mathrm{nd} 2(1.00)+\mathrm{nd} 4$ $(0.75)+\operatorname{nd} 6(0.50)+\operatorname{nd} 8(0.25)$; where nd2, nd4, nd6, nd8 are number of emerging seedlings on day 2, 4, 6, 8 [16].

Seedling vigor index (S.V.I.)

Seedling vigor index was calculated using this equation [17].

S. V.I Index $=$ Seedling length $(\mathrm{cm}) \mathrm{x}$ germination $\%$ age

Germination stress tolerance index (G.S.T.I.)

Germination was studied under stress conditions. For salt stressed treatments, seeds were irrigated with sodium chloride solution $(50 \mathrm{mM})$ for 1 day. For drought stressed treatments, irrigation was hold for 1 day. For heat stressed treatments, seeds were treated with high temperature 35 degree Celsius in incubator for $3 \mathrm{~min}$. Germination stress tolerance index (G.S.T.I) was calculated using following equation [16]

Germination stress tolerance index (G.S.T.I) $=$ Promptness index of stressed seeds /Promptness index of control seeds x 100 .

\section{Results}

\section{Germination analysis}

Germination Percentage:

Decrease in germination percentage (Fig.1) was observed in seeds exposed to drought, salt and heat stress as compared to control seeds. Under normal irrigation, $5 \mathrm{mM} \mathrm{KNO}_{3}$ 
was prominently effective among priming treatments with $42 \%$ increase as compare to control. Under drought conditions, hydro priming was most effective with $48 \%$ increase followed by $5 \mathrm{mM} \mathrm{KNO}_{3}$ with $32 \%$, $10 \mathrm{mM} \mathrm{KNO}_{3}$ with $25 \%, 5 \mathrm{mM} \mathrm{NaCl}$ with $12 \%$ and $10 \mathrm{mM} \mathrm{NaCl}$ with $6 \%$ increase in germination percentage as compared to drought stressed seeds. Under salt stress, $5 \mathrm{mM} \mathrm{KNO}_{3}$ priming resulted in highest germination percentage with $26 \%$ increase followed by $10 \mathrm{mM} \mathrm{KNO}_{3}$ with $11 \%$, hydro priming with $8 \%, 5 \mathrm{mM} \mathrm{NaCl}$ with $5 \%$ and $10 \mathrm{mM} \mathrm{NaCl}$ with $4 \%$ increase in germination percentage as compared to salt stressed seeds. Under heat stress, hydro priming was most effective with $33 \%$ increase followed by $5 \mathrm{mM} \mathrm{KNO}_{3}$ with $25 \%$, $10 \mathrm{mM} \mathrm{KNO}_{3}$ with $18 \%, 5 \mathrm{mM} \mathrm{NaCl}$ with $11 \%$ and $10 \mathrm{mM} \mathrm{NaCl}$ with $7 \%$ increase in germination percentage as compared to heat stressed seeds. When subjected to ANOVA, it was found that effect of seed priming remained significant $(\mathrm{p} \leq 0.05)$. Germination percentage of NARC-2009 variety was higher than NARC- 2011 variety on average.

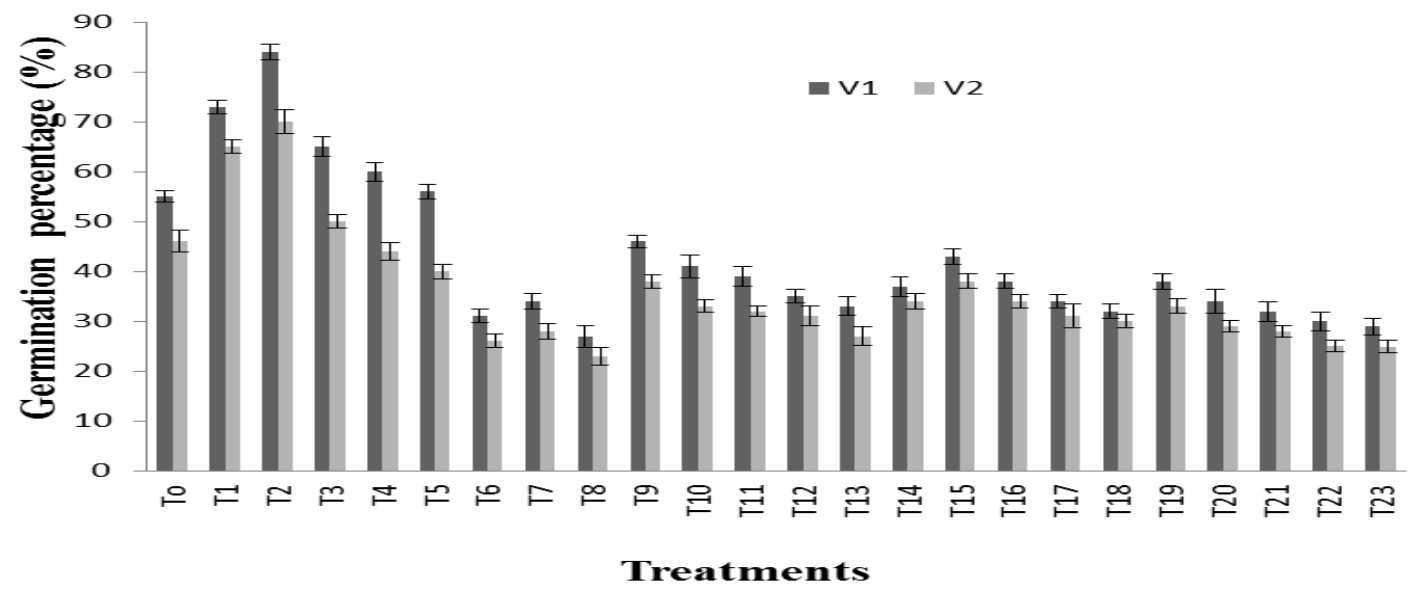

Fig. 1. Effect of Hydro priming, Osmo priming (5mM, $\left.10 \mathrm{mMKNO}_{3}\right)$ and halo priming $(5 \mathrm{mM}, 10 \mathrm{mM} \mathrm{NaCl})$ on germination percentage of two wheat varieties under drought, salt and heat stress.

To $=$ well watered and un primed, T1 $=$ hydro primed and well watered, T2 $=$ Osmo primed $\left(5 \mathrm{mM} \mathrm{KNO}_{3}\right)$ and well watered, T3= Osmo primed $\left(10 \mathrm{mM} \mathrm{KNO}_{3}\right)$ and well watered, $\mathrm{T} 4=$ halo primed $(5 \mathrm{mM} \mathrm{NaCl}$ )and well watered, $\mathrm{T} 5=$ Halo primed $(10 \mathrm{mMNaCl})$ and well watered, $\mathrm{T} 6=$ drought stressed, $\mathrm{T} 7=$ salt stressed, $\mathrm{T} 8=$ heat stressed, $\mathrm{T} 9=$ hydro primed and drought exposed, $\mathrm{T} 10=$ Osmo primed $\left(5 \mathrm{mM} \mathrm{KNO}_{3}\right)$ and drought exposed, $\mathrm{T} 11=$ Osmoprimed $10 \mathrm{mM} \mathrm{KNO}_{3}$ and drought exposed, T12= halo primed ( $5 \mathrm{mMNaCl}$ )and drought exposed, T13= Halo primed $(10 \mathrm{mMNaCl})$ and drought exposed, , T14 $=$ hydro primed and salt exposed, $\mathrm{T} 15=$ Osmo primed $\left(5 \mathrm{mM} \mathrm{KNO}_{3}\right)$ and salt exposed, $\mathrm{T} 16=$ Osmo primed $10 \mathrm{mM} \mathrm{KNO}_{3}$ and salt exposed, T17= halo primed ( $5 \mathrm{mM} \mathrm{NaCl}$ ) and salt exposed, $\mathrm{T} 18=$ Halo primed $(10 \mathrm{mM} \mathrm{NaCl})$ and salt exposed, $\mathrm{T} 19=$ hydro primed and heat exposed, $\mathrm{T} 20=$ Osmo primed $\left(5 \mathrm{mM} \mathrm{KNO}_{3}\right)$ and heat exposed, $\mathrm{T} 21=$ Osmoprimed $10 \mathrm{mM} \mathrm{KNO}_{3}$ and heat exposed, T22= halo primed ( $5 \mathrm{mMNaCl}$ )and heat exposed, $\mathrm{T} 23=$ Haloprimed $(10 \mathrm{mMNaCl})$ and heat exposed. $\mathrm{V} 1=\mathrm{NARC}-2009$ and $\mathrm{V} 2=$ NARC-2011

\section{Germination Index:}

Germination index (Fig. 2) was drastically reduced under drought, salt and heat stress as compare to control. Under well watered 
conditions, $5 \mathrm{mM} \mathrm{KNO}_{3}$ was most effective with $36 \%$ increase as compared to control. Under drought stress, hydro priming showed $70 \%$ increase in germination index followed by $5 \mathrm{mM} \mathrm{KNO}_{3}$ with $61 \%, 10 \mathrm{mM}^{\mathrm{KNO}_{3}}$ with $45 \%, 5 \mathrm{mM} \mathrm{NaCl}$ with $24 \%$ and $10 \mathrm{mM}$ $\mathrm{NaCl}$ with $6 \%$ increase in germination index as compared to drought stressed seeds. Under salt stress, $5 \mathrm{mM} \mathrm{KNO}_{3}$ priming resulted in highest germination index with $75 \%$ increase followed by $10 \mathrm{mM}^{\mathrm{KNO}_{3}}$ with $69 \%$, hydro priming with $58 \%, 5 \mathrm{mM}$ $\mathrm{NaCl}$ with $20 \%$ and $10 \mathrm{mM} \mathrm{NaCl}$ with $9 \%$ increase in germination index as compared to stressed seeds. Under heat stress, hydro priming was most effective with $65 \%$ increase followed by $5 \mathrm{mM} \mathrm{KNO}_{3} 75 \%$, $10 \mathrm{mM} \mathrm{KNO}_{3}$ with $71 \%, 5 \mathrm{mM} \mathrm{NaCl}$ with $23 \%$ and $10 \mathrm{mM} \mathrm{NaCl} 7 \%$ increase in germination index as compared to stressed seeds. Results showed $(p \leq 0.05)$ when subjected to statistical analysis.

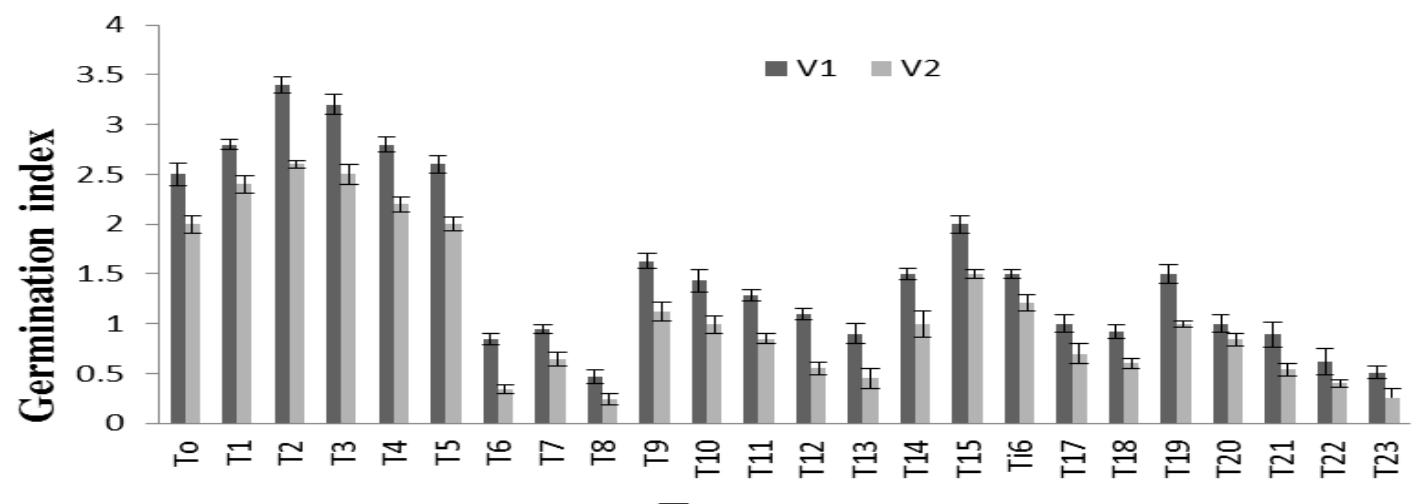

Treatments

Fig. 2. Effect of Hydro priming, Osmo priming (5mM, $10 \mathrm{mMKNO}$ ) and halo priming $(5 \mathrm{mM}, 10 \mathrm{mM} \mathrm{NaCl})$ on germination index of two wheat varieties under drought, salt and heat stress.

To $=$ well watered and un primed, $\mathrm{T} 1=$ hydro primed and well watered, T2 $=$ Osmo primed $(5 \mathrm{mM} \mathrm{KNO} 3)$ and well watered, $\mathrm{T} 3=$ Osmo primed $\left(10 \mathrm{mM} \mathrm{KNO}_{3}\right)$ and well watered, $\mathrm{T} 4=$ halo primed ( $5 \mathrm{mM} \mathrm{NaCl}$ ) and well watered, T5 $=$ Halo primed $(10 \mathrm{mMNaCl})$ and well watered, T6 $=$ drought stressed, $\mathrm{T} 7=$ salt stressed, $\mathrm{T} 8=$ heat stressed, $\mathrm{T} 9=$ hydro primed and drought exposed, $\mathrm{T} 10=$

Osmo primed $\left(5 \mathrm{mM} \mathrm{KNO}_{3}\right)$ and drought exposed, $\mathrm{T} 11=$ Osmo primed $10 \mathrm{mM} \mathrm{KNO}_{3}$ and drought exposed, T12 $=$ halo primed ( $5 \mathrm{mMNaCl}$ )and drought exposed, $\mathrm{T} 13=$ Halo primed (10mMNaCl) and drought exposed, , T14 $=$ hydro primed and salt exposed, $\mathrm{T} 15=$ Osmo primed $\left(5 \mathrm{mM} \mathrm{KNO}_{3}\right)$ and salt exposed, T16 $=$ Osmo primed $10 \mathrm{mM} \mathrm{KNO}_{3}$ and salt exposed, T17= halo primed ( $5 \mathrm{mM} \mathrm{NaCl}$ )and salt exposed, $\mathrm{T} 18=$ Halo primed $(10 \mathrm{mM} \mathrm{NaCl})$ and salt exposed, $\mathrm{T} 19=$ hydro primed and heat exposed, T20 $=$ Osmo primed $\left(5 \mathrm{mM} \mathrm{KNO}_{3}\right)$ and heat exposed, T21 $=$ Osmo primed $10 \mathrm{mM} \mathrm{KNO}_{3}$ and heat exposed, T22 = halo primed ( $5 \mathrm{mMNaCl}$ )and heat exposed, T23 $=$ Halo primed $(10 \mathrm{mM} \mathrm{NaCl})$ and heat exposed. V1= NARC-2009 and V2= NARC-2011

\section{Promptness Index:}

Promptness index (Fig. 3) was reduced under drought, salt and heat stressed seeds. Under well watered conditions, $5 \mathrm{mM} \mathrm{KNO}_{3}$ resulted in highest promptness index with $31 \%$ increase as compared to control. Under water stress, hydro primed seeds showed $80 \%$ increase in promptness index followed by $5 \mathrm{mM} \mathrm{KNO}_{3}$ with $75 \%, 10 \mathrm{mM} \mathrm{KNO}_{3}$ with $69 \%, 5 \mathrm{mM} \mathrm{NaCl}$ with $13 \%$ and $10 \mathrm{mM}$ $\mathrm{NaCl}$ with $4 \%$ increase as compared to drought stressed seeds. Under salinity stress, $5 \mathrm{mM} \mathrm{KNO}_{3}$ primed showed. 


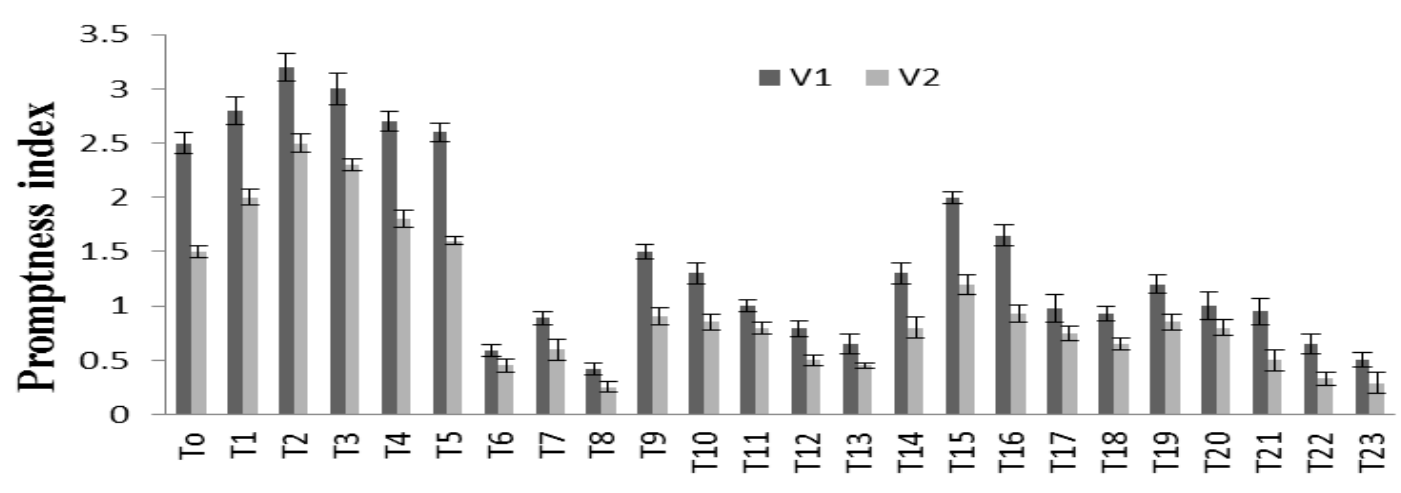

Treatments

Fig. 3. Effect of Hydro priming, Osmo priming $(5 \mathrm{mM}, 10 \mathrm{mMKNO})$ and halo priming $(5 \mathrm{mM}, 10 \mathrm{mM} \mathrm{NaCl})$ on promptness index of two wheat varieties under drought, salt and heat stress.

To= well watered and un primed, $\mathrm{T} 1=$ hydro primed and well watered, T2 $=$ Osmo primed $\left(5 \mathrm{mM} \mathrm{KNO}_{3}\right)$ and well watered, $\mathrm{T} 3=$ Osmo primed $\left(10 \mathrm{mM} \mathrm{KNO}_{3}\right)$ and well watered, $\mathrm{T} 4=$ halo primed $(5 \mathrm{mM} \mathrm{NaCl}$ )and well watered, T5 $=$ Halo primed $(10 \mathrm{mMNaCl})$ and well watered, $\mathrm{T} 6=$ drought stressed, $\mathrm{T} 7=$ salt stressed, $\mathrm{T} 8=$ heat stressed, $\mathrm{T} 9=$ hydro primed and drought exposed, T10= Osmo primed $\left(5 \mathrm{mM} \mathrm{KNO}_{3}\right)$ and drought exposed, $\mathrm{T} 11=$ Osmo primed $10 \mathrm{mM} \mathrm{KNO}_{3}$ and drought exposed, T12 $=$ halo primed ( $5 \mathrm{mMNaCl}$ )and drought exposed, T13= Halo primed $(10 \mathrm{mMNaCl})$ and drought exposed, , $\mathrm{T} 14=$ hydro primed and salt exposed, $\mathrm{T} 15=$ Osmo primed $(5 \mathrm{mM} \mathrm{KNO} 3)$ and salt exposed, T16 $=$ Osmo primed $10 \mathrm{mM} \mathrm{KNO}_{3}$ and salt exposed, T17= halo primed ( $5 \mathrm{mM} \mathrm{NaCl}$ )and salt exposed, $\mathrm{T} 18=$ Halo primed $(10 \mathrm{mM} \mathrm{NaCl})$ and salt exposed, , T19 $=$ hydro primed and heat exposed, $\mathrm{T} 20=$ Osmo primed $\left(5 \mathrm{mM} \mathrm{KNO}_{3}\right)$ and heat exposed, T21 = Osmo primed $10 \mathrm{mM} \mathrm{KNO}_{3}$ and heat exposed, T22= halo primed ( $5 \mathrm{mMNaCl}$ )and heat exposed, $\mathrm{T} 23=$ Halo primed $(10 \mathrm{mM} \mathrm{NaCl})$ and heat exposed. V1= NARC-2009 and V2= NARC-2011

$89 \%$ increase in promptness index followed by $10 \mathrm{mM} \mathrm{KNO}_{3}$ with $85 \%$, hydro priming with $46 \%, 5 \mathrm{mM} \mathrm{NaCl}$ with $15 \%$ and $10 \mathrm{mM}$
$\mathrm{NaCl}$ with $6 \%$ increase as compared to stressed seeds. Under heat stress, hydro priming was most effective with $75 \%$ increase followed by $5 \mathrm{mM} \mathrm{KNO}_{3}$ with $60 \%$, $10 \mathrm{mM} \mathrm{KNO}_{3}$ with $55 \%, 5 \mathrm{mM} \mathrm{NaCl}$ with $12 \%$ and $10 \mathrm{mM} \mathrm{NaCl} 2 \%$ increase in promptness index as compared to stressed seeds. Variance analysis of promptness index showed significant results $(\mathrm{p} \leq 0.05)$ in both the varieties.

\section{Seedling Vigor Index:}

A very pronounced effect of seed priming was seen on seedling vigor index. Seed priming was effective under well watered conditions as well as stress conditions. $5 \mathrm{mM}$ $\mathrm{KNO}_{3}$ was prominently most effective under well water conditions and caused a $49 \%$ increase as compare to control (Fig.4). Under drought stress, hydro priming showed $79 \%$ increase in seedling vigor index followed by $5 \mathrm{mM} \mathrm{KNO}_{3}$ with $67 \%, 10 \mathrm{mM}$ $\mathrm{KNO}_{3}$ with $41 \%, 5 \mathrm{mM} \mathrm{NaCl}$ with $11 \%$ and $10 \mathrm{mM} \mathrm{NaCl}$ with $5 \%$ increase in seedling vigor index as compared to stressed seeds. Under salt stress, $5 \mathrm{mM} \mathrm{KNO}_{3}$ priming resulted in highest seedling vigor index with $86 \%$ increase followed by $10 \mathrm{mM} \mathrm{KNO}_{3}$ with $64 \%$, hydro priming with $41 \%, 5 \mathrm{mM}$ $\mathrm{NaCl}$ with $8 \%$ and $10 \mathrm{mM} \mathrm{NaCl}$ with $5 \%$ increase in seedling vigor index as compared to stressed seeds. Under heat stress, hydro 
priming was most effective with $70 \%$ increase followed by $5 \mathrm{mM} \mathrm{KNO}_{3} 57 \%$, $10 \mathrm{mM} \mathrm{KNO}_{3} 17 \%, 5 \mathrm{mM} \mathrm{NaCl}$ with $4 \%$ and $10 \mathrm{mM} \mathrm{NaCl} 2 \%$ increase in seedling vigor index as compared to stressed seeds. Results were significant $(\mathrm{p} \leq 0.05)$ when subjected to ANOVA. Significant difference was observed among both varieties.

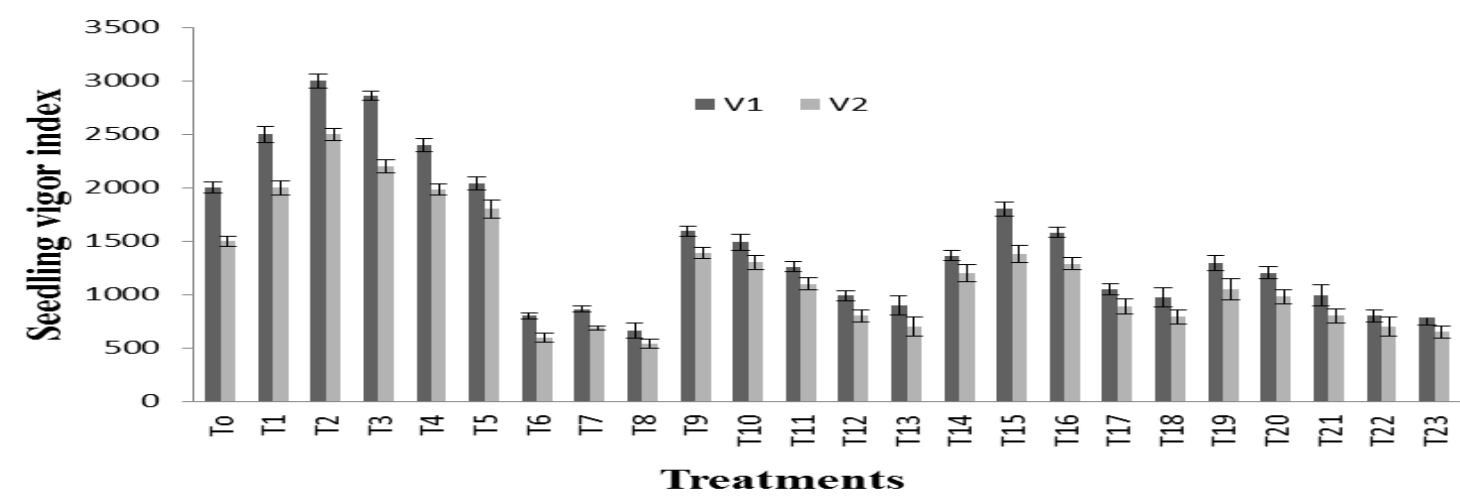

Fig. 4. Effect of Hydro priming, Osmo priming (5mM, $10 \mathrm{mMKNO}$ ) and halo priming $(5 \mathrm{mM}, 10 \mathrm{mM} \mathrm{NaCl})$ on Seedling vigor index of two wheat varieties under drought, salt and heat stress.

To= well watered and un primed, T1= hydro primed and well watered, T2 $=$ Osmo primed $\left(5 \mathrm{mM} \mathrm{KNO}_{3}\right)$ and well watered, T3= Osmo primed $\left(10 \mathrm{mM} \mathrm{KNO}_{3}\right)$ and well watered, $\mathrm{T} 4=$ halo primed $(5 \mathrm{mM} \mathrm{NaCl}$ ) and well watered, $\mathrm{T} 5=$ Halo primed $(10 \mathrm{mMNaCl})$ and well watered, $\mathrm{T} 6=$ drought stressed, $\mathrm{T} 7=$ salt stressed, $\mathrm{T} 8=$ heat stressed, $\mathrm{T} 9=$ hydro primed and drought exposed, $\mathrm{T} 10=$ Osmo primed $\left(5 \mathrm{mM} \mathrm{KNO}_{3}\right)$ and drought exposed, $\mathrm{T} 11=$ Osmo primed $10 \mathrm{mM} \mathrm{KNO}_{3}$ and drought exposed, T12 $=$ halo primed ( $5 \mathrm{mMNaCl}$ )and drought exposed, T13= Halo primed $(10 \mathrm{mMNaCl})$ and drought exposed, , T14 $=$ hydro primed and salt exposed, $\mathrm{T} 15=$ Osmo primed $\left(5 \mathrm{mM} \mathrm{KNO}_{3}\right)$ and salt exposed, $\mathrm{T} 16=$ Osmo primed $10 \mathrm{mM} \mathrm{KNO}_{3}$ and salt exposed, $\mathrm{T} 17=$ halo primed ( $5 \mathrm{mM} \mathrm{NaCl}$ ) and salt exposed, $\mathrm{T} 18=$ Halo primed $(10 \mathrm{mM} \mathrm{NaCl})$ and salt exposed, , T19 $=$ hydro primed and heat exposed, T20 $=$ Osmo primed $\left(5 \mathrm{mM} \mathrm{KNO}_{3}\right)$ and heat exposed, T21 $=$ Osmo primed $10 \mathrm{mM} \mathrm{KNO}_{3}$ and heat exposed, $\mathrm{T} 22=$ halo primed ( $5 \mathrm{mMNaCl}$ )and heat exposed, $\mathrm{T} 23=$ Halo primed $(10 \mathrm{mM} \mathrm{NaCl})$ and heat exposed. V1= NARC-2009 and V2= NARC-2011
Germination Stress Tolerance Index:

Germination stress tolerance index (fig.5) was reduced under drought, salt and heat stressed seeds. Under water stress, hydro primed seeds showed $55 \%$ increase in germination stress tolerance index followed by $5 \mathrm{mM}$ KNO3 with $37 \%, 10 \mathrm{mMKNO} 3$ with $24 \%, 5 \mathrm{mM} \mathrm{NaCl}$ with $10 \%$ and $10 \mathrm{mM}$ $\mathrm{NaCl}$ with $3 \%$ increase as compared to stressed seeds. Under salinity stress, $5 \mathrm{mM}$ KNO3 primed showed $51 \%$ increase in germination tolerance index followed by $10 \mathrm{mM}$ KNO3 with $42 \%$, hydro priming with $31 \%, 5 \mathrm{mM} \mathrm{NaCl}$ with $15 \%$ and $10 \mathrm{mM} \mathrm{NaCl}$ with $5 \%$ increase as compared to stressed seeds. Under heat stress, hydro priming was most effective with $45 \%$ increase followed by $5 \mathrm{mM}$ KNO3 39\%, 10mM KNO3 with 30 $\%, 5 \mathrm{mM} \mathrm{NaCl}$ with $11 \%$ and $10 \mathrm{mM} \mathrm{NaCl}$ $2 \%$ increase in germination stress tolerance index as compared to stressed seeds. Variance analysis of germination stress tolerance index showed significant results ( $\mathrm{p}$ $\leq 0.05$ ) in both the varieties NARC-2009 variety showed more tolerance towards stress conditions as compared to NARC2011 variety. 


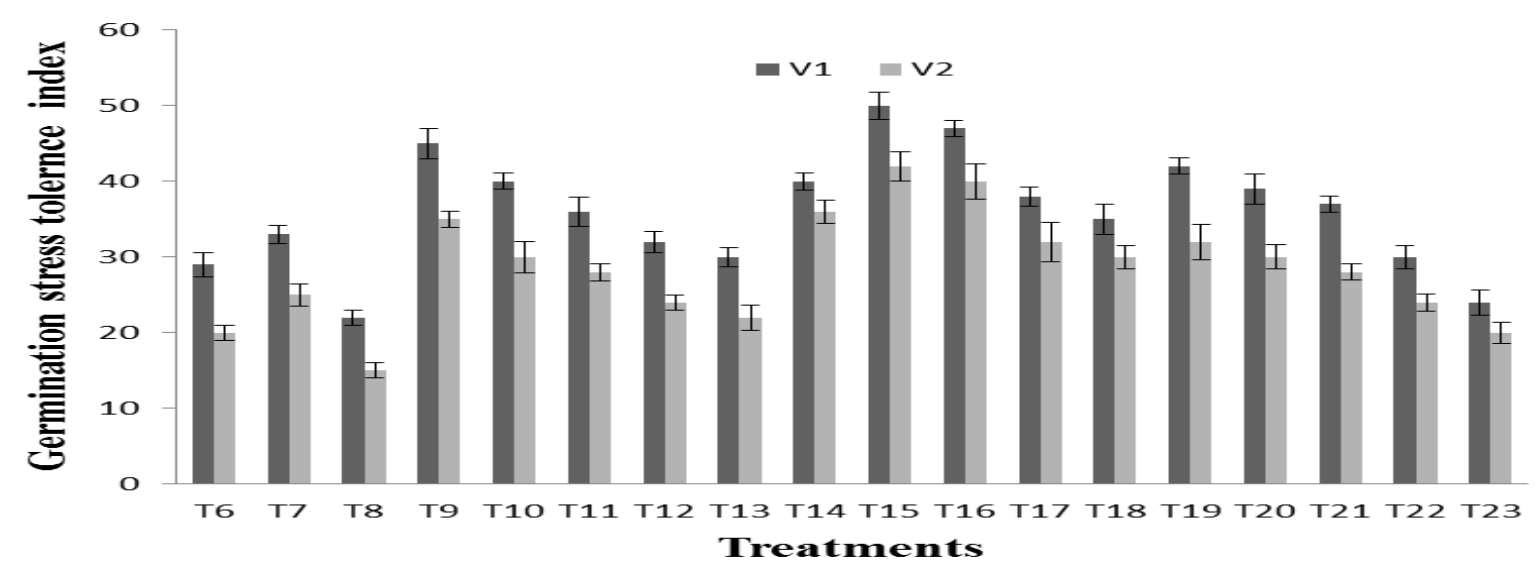

Fig. 5. Effect of Hydro priming, Osmo priming (5mM, $\left.10 \mathrm{mMKNO}_{3}\right)$ and halo priming $(5 \mathrm{mM}, 10 \mathrm{mM} \mathrm{NaCl})$ on Germination stress tolerance index of two wheat varieties under drought, salt and heat stress.

$\mathrm{T} 6=$ drought stressed, $\mathrm{T} 7=$ salt stressed, $\mathrm{T} 8=$ heat stressed, $\mathrm{T} 9=$ hydro primed and drought exposed, $\mathrm{T} 10=$ Osmo primed $\left(5 \mathrm{mM} \mathrm{KNO}_{3}\right)$ and drought exposed, T11= Osmo primed $10 \mathrm{mM} \mathrm{KNO}_{3}$ and drought exposed, T12= halo primed ( $5 \mathrm{mMNaCl}$ )and drought exposed, T13 $=$ Halo primed $(10 \mathrm{mM} \mathrm{NaCl})$ and drought exposed, , T14= hydro primed and salt exposed, T15= Osmo primed $(5 \mathrm{mM}$ $\mathrm{KNO}_{3}$ ) and salt exposed, $\mathrm{T} 16=$ Osmo primed $10 \mathrm{mM} \mathrm{KNO}_{3}$ and salt exposed, $\mathrm{T} 17=$ halo primed $(5 \mathrm{mM} \mathrm{NaCl})$ and salt exposed, T18 $=$ Halo primed $(10 \mathrm{mM} \mathrm{NaCl})$ and salt exposed, , T19= hydro primed and heat exposed, T20 $=$ Osmo primed $(5 \mathrm{mM}$ $\mathrm{KNO}_{3}$ ) and heat exposed, $\mathrm{T} 21=$ Osmo primed $10 \mathrm{mM} \mathrm{KNO}_{3}$ and heat exposed, $\mathrm{T} 22=$ halo primed $(5 \mathrm{mMNaCl})$ and heat exposed, T23 $=$ Halo primed $(10 \mathrm{mM} \mathrm{NaCl})$ and heat exposed. V1= NARC-2009 and V2= NARC-2011

\section{Discussion}

On account of global environmental changes, drought, salinity and high temperature are important stresses that cause a limitation in crop establishment, growth and productivity. According to these situations, present work was planned to improve germination, morphology, physiology and biochemical attributes of crop by use of seed priming technology in relation to abiotic stress tolerance. Different priming strategies were used in order to screen the most effective seed priming under different stress conditions. Even and fast germination are two important factors required for crop assemblage. Seed soaking technology is used to enhance the seed performance and even germination and improved seedling establishment in many plants [18]. Break down of seed dormancy is possible by priming and thus enhances rate of germination under different ranges of environmental changes [10].

During present work, it was found that germination and seedling growth was greatly influenced under stress conditions. Under drought stress, germination was decreased due to shortage of water required for early processes of germination. Salinity had a toxic effect on germinating seeds and excessive salt hinders seeds from water uptake during germination due to decreased solute potential. High range of temperature caused a reduction in seed germination rate and seedling growth because high temperature effects enzyme functions and initiates drought. These results agree with findings of [19]. In present study, it was found that hydro priming had a profound effect on seed germination, tolerance and seedling vigor index under drought and heat stress. This is due to the fact that hydropriming initiates many mechanisms 
such as renovation and production of nucleic acids, protein, membrane repair and many biochemical processes in relation to enzyme activation. Even germination of hydroprimed seeds is probably due to improvement in water uptake, ATP synthesis and cell division. Primed seeds can better imbibe water than stressed seeds thus enhancing tolerance under stress conditions. Metabolism is also stimulated by priming which helps in early emergence of radical and plumule. Same were the findings of $[20,21,22]$ who previously found that hydro priming increased germination and seedling vigor of cotton and melon. Present study also revealed that Osmo priming was proved to be best treatment under saline conditions improving tolerance, germination properties and seedling vigor. This is due to effect of osmo priming on oxidative metabolism by increasing activity of anti oxidant enzymes such as peroxidase and superoxide dismutase. Osmopriming also stimulates ATPase function, RNA processing and water uptake by acting as a osmoticum. Results agree with the findings of $[23,24$, 25]. The reason for increasing salinity tolerance in the plants grown from primed seeds is due to higher capacity of seeds adapted to osmotic conditions. $\mathrm{KNO}_{3}$ priming was proved to be effective in decreasing salt effects of different varieties like chickpea, sunflower.

\section{Authors' contributions}

Conceived and designed the experiments: $\mathrm{N}$ Ilyas, Performed the experiments: SR Mirza, Analyzed the data: N Batool \& N Ilyas, Contributed reagents/materials/analysis tools: N Ilyas, Wrote the paper: SR Mirza \& N Batool.

\section{References}

1. Farooq M, Wahid A, Fujita NKD, \& Basra SMA (2009). Plant drought stress: effects, mechanisms and management. Agro for Sustainable Develop 29: 185-212.
2. Mandhania S, Madan S, Sawhney V, \& Haryana CCS (2006). Antioxidant defense mechanism under salt stress in wheat seedlings. Biologia Plant 50(2): 227-231.

3. Michael PF, Jalal HH, Hail ZR \& Mohammad AI (2012). Germination of Primed Seed under $\mathrm{NaCl}$ Stress in Wheat. International scholarly res notices. http://dx.doi.org/10.5402/2012/167804

4. Wahid A, Gelani S, Ashraf M, \& Foolad R (2007). Heat tolerance in plants: An overview. Envi and Exp Bot 61(3): 199 $-223$.

5. Harris D, Tripathi RS, \& Joshi A (2000). On- farm priming to improve crop establishment and yield in directseeded rice in IRRI : intemational Workshop on Dry -seeded Rice Technology,5 - 28 January. The international Rice Research institute, Manila, 164.

6. Janick J, Assche JV, Dijick KV, \& Weststeiujn G (2004). Horticulture highlights. Chronica Horti. 44(2): 1718.

7. Golezanik G, Aliloo AA, Valizadeh M, \& Moghaddam M (2008). Effects of Hydro and osmopriming on seed germination and field emergence of Lentil (Lens culinaris Medik.). Notulae Botanicae Horti Agrobot Cluj-Napoca. 36(1): 29-33.

8. Demire M, Okcu G, Atak M, Cikili Y, \& Kalsarizi O (2006). Seed treatment to overcome salt and drought stress during germination in Sun flower (Helianthus annuus L.). European J of Agro. 24: 291-295.

9. Murungu FS, Nyamugafata $P$, Chiduza $C$, Clark LJ, \& Whalley WR (2003). Effects of seed priming aggregate size and soil matrix potential on emergence of cotton (Gossypium hirsutum L.) and 
maze (Zea mays L.). Soil and Tillage Res 74: 161-168.

10. Afzal I, Basra SMA, Ahmad N, Cheema MA, Warraich EA, \& Khaliq A (2002). Effect of priming and growth regulator treatment on emergence and seedling growth of hybrid maize (Zea mays). International J of Agri and Biol 4: 303306.

11. Mabhaudhi T, \& Modi AT (2011). Can Hydro- Priming improves germination speed, vigour and emergence of maize landraces under water stress. J of Agri Sci and Tech 20-28.

12. Qadir I, Khan ZH, Khan RA, \& Afzal I (2011). Evaluating the potential of seed priming techniques in improving germination and early seedling growth of various rangeland grasses. Pak $\mathbf{J}$ of Bot 43(6): 2797-2800

13. Basra SMA, Afzal I, Anwar S, Shafique M, Haq A, \& Majeed K (2005). Effect of different seed invigoration techniques on wheat (Triticum aestivum L.) seeds sown under saline and non - saline conditions. J of Seed Tech 28: 36 - 45.

14. Nichols PGH, Malik AI, \& Stockdale M (2009). Salt tolerance and avoidance mechanisms at germination of annual pasture legumes: importance for adaptation to saline environments. Plant Soil 315: 241-255.

15. ISTA, 2005. International rules for seed testing. International Seed Testing Association. Zurich, Switzerland.

16. Noreen Z, Ashraf M, \& Hassan MU (2007). Inter-accessional variation for salt tolerance in pea (Pisum sativum L.) at germination and screening stage. Pak J of Bot 39(6): 2075-2085.

17. Abdulbaki A, \& Anderson JD (1973). Vigor determination in Soybean seed by multiple criteria. Crop Sci. 13: 630 633.

18. Taylor AG, Allen PS, Bennett MA, Bradford KJ, Burris JS, \& Misra MK (1998). Seed Sci Res 8: 245 - 256.

19. Achakzai AKK (2011). Effect of water stress on imbibition, germination and seedling growth of sorghum cultivars. Sarhad J Agri 27(4): 603-610.

20. Sheidaie S, Divasalar M, Oskouei B, Sadegi H, \& Rezvani E (2013). Seed hydro-priming application to alleviation of water stress during germination in sunflower hybirds (Helianthus annuus L.). International $\mathbf{J}$ of Agri and Crop Sci 5: 155- 159.

21. Ascherman-Koch C, Hofmann P, \& Steiner AM (1992). Pre- sowing treatment for improving quality in cereals. Seed Sci Tech 20: 435-440.

22. Casenave EC, \& Toselli ME (2007). Hydropriming as a pre-treatment for cotton germination under thermal and water stress conditions. Seed Sci and Tech 35: 88-98.

23. Jie LL, Ong S, Dong MO, Fang L, \& Hua EW (2002). Effect of PEG on germination and active oxygen metabolism in wild rye (Leymus Chinesis) seed. Acta Prata CultSinica 11: 59- 64.

24. Sarwar N, Yousaf S, \& Jamil FF (2006). Induction of salt tolerance in chickpea by using simple and safe chemicals. Pak J of Bot 38: 325- 329.

25. Sivritepe N, Sivritepe HO, \& Eris A (2003). The effects of $\mathrm{NaCl}$ priming on salt tolerance in melon seedling growth under saline conditions. Scientia Horti 97: 229- 237. 